A Bibliography of Sir Oliver Lodge, F.R.S. Compiled by Theodore Besterman. Pp. xiv +220 . (London: Oxford University Press, 1935.) 21s. net. Srr OLIver Lodge has for many years been a clear and prolific writer on many subjects, and Mr. Besterman has collected a list of 1,156 books, pamphlets, articles, letters, notes, etc., in scientific, technical and other journals and books written by Sir Oliver in the past sixty years. Of these, 247 relate to electricity and wireless communication, 54 to questions concerning the ether, 289 to other scientific subjects, 70 to psychical research in general, 73 to survival after death, 64 to education, 170 to philosophy and religion, 118 are biographical or are reviews of or prefaces to books by other authors and 71 are on miscellaneous subjects. An index of 23 pages, which distinguishes typographically between books and pamphlets on one hand and contributions to periodicals on the other, facilitates reference to the book.

In the preface, Sir Oliver has added some further information as to his early demonstration of wireless signalling at the meeting of the British Association at Oxford in 1894, and the developments which followed. The book is well printed, and the portrait of Sir Oliver which forms the frontispiece is very good and shows him in a characteristic attitude. An absence of cross references throughout the book makes it difficult to follow the course of discussions on psychical or religious subjects between Sir Oliver and his crities. Sometimes a reply is tabulated without the criticism, at others the criticism without a reply, as for example, Sir Herbert Stephen's criticism of "Raymond" on p. 111. No hint is given that Prof. Armstrong's article, xxi p. 191, entitled "Sir Oliver Lodge, Intolerant, Infallible", is the fourth member of a quartette, the others being Sir Oliver devi p. 102, Sir Ray Lankester xxix p. 191, Sir Oliver dcxi, p. 103. The roman numerals for articles throughout the book, as for example, "Science and Psychical Research dccccxlviii", instead of 948, p. 215, of the index, detract considerably from the ease of reference to the Bibliography.

\section{The Origins of Religion}

By Prof. Rafael Karsten. Pp. viii +328. (London : Kegan Paul and Co., Ltd., 1935.) 12s. 6d. net.

Prof. Karsten, in formulating his theories of the origins of primitive religion, is in a position to draw upon an extensive acquaintance with the beliefs of backward peoples, especially in South America, at first hand. He is thus able to meet the more serious critics of the comparative method in the study of religion on their own ground, when they impute neglect or ignorance of the context as a fatal flaw in the argument. On the other hand, although he him. self maintains the predominance of animism and ancestor worship as formative influences in the religious side of man's cultural development, he points out that those who have followed Tylor and Spencer have frequently been entirely uncritical in the use of authorities upon whose evidence they have based the evolutionary view of the growth of religion.
Prof. Karsten is to be regarded as in the main an evolutionist, though he is no upholder of the crude view of a unilateral line of development. On the other hand, he is ready to recognise that diffusion and kulturkreise are not to be ruled out, and that they, too, have played their part. Preanimism or animatism, however, finds no favour as a precedent to animism, and is regarded as late and sophisticated.

The book is an excellent and well-balanced review of current theory and reinterpretation of the evidence in the light of personal first-hand knowledge. Its value is enhanced by the use the author has made of evidence afforded by the beliefs of Finno-Ugrian peoples which, owing to difficulties of language, are not generally accessible.

\section{Terrains, roches et fossiles de la Belgique}

Par Eug. Maillieux. Deuxième édition, revue et augmentée. Pp. 217. (Bruxelles: Musée royal d'Histoire naturelle de Belgique, 1933.) 6 belgas.

THIs work is an excellent summary of the present state of knowledge of the stratigraphical geology and palæontology of Belgium, and while invaluable to geologists, sufficient explanatory matter is given to make the book of use to readers with only a small knowledge of the subject. With the exception of the Cambrian system, the range of formations is almost as extensive as in the British Isles, and the deposits, in the main, resemble those of these islands. The palæontological record really starts with the Tremadocian, there being no definite evidence to show whether earlier formations are of Cambrian or pre-Cambrian age. Three maps show the outcrops of Palæozoic, Mesozoic and Tertiary formations respectively, from which it is seen that the Mesozoic deposits occupy a relatively small area, the Palæozoic form most of the southern part of the country, and the Tertiary the northern part. Intrusive and extrusive igneous rocks are of little importance.

The palæontology of each system and its divisions are lucidly described and illustrated by numerous figures. Interest is given to the stratigraphical facts by an account of the conditions under which the deposits were formed and of the geographical changes which took place during each period. A new section across the Ardennes by Prof. F. Kaisin is welcome.

\section{Opera hactenus inedita Rogeri Baconi}

Fasc. 12 : Questiones supra librum de Causis. Nunc primum edidit Robert Steele, collaborante Ferdinand M. Delorme, Accedit Liber de Causis a Roberto Steele. Pp. xxiv + 196. (Oxford: Clarendon Press; London: Oxford University Press, 1935.) 17s.6d. net. THrs excellent edition of Bacon's commentary on the "Liber de Causis" brings nearer to completion the publication of the works of the erudite Franciscan friar of the Middle Ages. The thesis and the commentary are printed separately, following the method used by medieval writers. The history of the MSS. used for this edition is given by Mr. Steele in a comprehensive introduction. The work deals with some fundamental points of ontology, such as being, substance, cause and the intellect. T. G. 